\title{
THE ACTUALIZATION OF THE INCREASED COMPETITIVENESS OF OIL PRODUCTS RUB HERBACEOUS TRADITIONALLY THROUGH BRANDING AND CERTIFICATION OF PRODUCT QUALITY ASSURANCE UMK RAMBAL DELI IN KECAMATAN GALANG
}

\author{
Roza Thohiri $^{1 *}$, Andri Zainal ${ }^{1}$, Pasca Dwi Putra ${ }^{1}$, Joko Suharianto ${ }^{1}$ \\ ${ }^{1}$ Faculty of Economics, Medan State University, Medan, Indonesia \\ *Corresponding Author: rozatho@unimed.ac.id
}

\begin{abstract}
The activities of the CPM with the title of "the Actualization of the Improvement of the Competitiveness of the Product Oil Scrub Traditional Herbs Through Branding and Certification Guarantee the Quality of Products UMK Rambal Deli in District Girders" this is focused on penuntasan 3 (three) problems specific be problem specific namely (1) Absence of the actualization of the knowledge explicit (explicit knowledge) in the product oil rub the traditional herbs that is produced; (2) product competitiveness the relative weakness with the management of production, marketing and finance is still traditional and; (3) the Body efforts yet there the body order official and permit the efforts which have not yet registered. Partners involved in the activities of the CPM this is the UMK Rambal Deli led by Mr. Agus Hidayat. UMK is located in the Street Sergeant M. Arifin gg. Muslim Lk. II wards Girders of the City, Subdistrict Girders, Regency of Deli Serdang. As an alternative solution for the settlement of the problem referred to consists of: (1) documentation of the profile and the formula of the products in print and electronic; (2) modernization and amplification of diffuse marketing: finishing and marketing system, and; (3) the assitance management certificate stand SME and business licenses. The activities of the CPM this will produce some external of them: The Proceedings, the Application of ABOUT and Product Innovation, draft pocket book, assitance management certificate stand order and clearance order.
\end{abstract}

Keywords: SME, Certificate of Incorporation, Business license, Packaging.

\section{INTRODUCTION}

The existence of oil rub has long since become part in the life of the people of Indonesia. It functions not only as a lubricant to lubricate the chuck or hand massage when the body feels tired or when one of the members of the body experiencing a shift in joints or fractures believed to have been the practice of local wisdom handed down by generations of predecessors. It is characterized through the utilization of raw materials from a variety of local vegetation that thrives in the land of the archipelago with the technique peramuan simple yet able to produce the means healer with side effects on the level of most minimum. As quoted from one of the blog sales oil rub the traditional (http://tokomuslim.biz/al-masyhur-minyak-gosok-herbal/), warm effect which is caused when rub oil applied topically caused by dilation of blood vessels in the surface of the skin which makes the blood circulation becomes more smoothly so that it can cause a sense of warmth and can relieve pain or pain. A variety of techniques peramuan and compounding plants-local plants have been making the nation of Indonesia as herbalist reliable ability passed down through the generations up to the present generation.

Obviously, every region in Indonesia has oil rub made from herbs. As such, eucalyptus oil from Ambon, oil wasps from Leeds and telon oil from Central Java relatively have been known and widely used in Indonesia. In general, oiloil which is meant the relative has the same efficacy that is in addition as a lubricant for the massage as above in the previous paragraph; oil rub of herbs that also serve as heating bodies, healer of wounds and a healer of diseases itching caused by insect bites by the use of the same raw material i.e. spices, roots, and coconut oil. Specialy in North Sumatra, one of the oils rub the most famous herbal of good efficacy or whereabouts is the oil Karo. Peramuan using natural raw materials such also have the power save long time although without any chemical ingredients.

Mr Agus Hidayat is a citizen who has long been known as a herbalist in Kecamatan Galang, Kabupaten Deli Serdang. His ability to mix a variety of herbs local to be diverse folk remedies like rubbing oil, a concoction of drinks bandrek, herb parasite of coffee and rub oil-based parasite coffee has long been known and transmitted to local residents and several groups of students doing field studies of various universities in North Sumatra. But until now only he was the one who consistently produces a variety of traditional herbal medicine with the maintained quality. 
Ability herbalist he obtained from his father as the running time of a row updated follow perantauannya to various regions in Indonesia. Until recently, he was the one and only motor driving the production of various herb medicines and there is not one publication of any that have been produced from a variety of activities, production related to the protection of intellectual property he. This condition reflects the dominance of innate knowledge (tacit knowledge), which is owned by him which is not accompanied by the actualization of the explicit knowledge (explicit knowledge) that can bring added value for him as the herbalist for the individual and to the herbal products that it produces. So, the protection of intellectual capital (intellectual capital) became one of the main focus of the proposed community service activities.

One of the herbal medicinal products most in demand sales is oil rub the herbs with two types of levels of heat which is very hot and warm. Both of these products already have a market with a limited number of customers-customers who have had good relations since a long time with him. Customers are referred to generally in addition of the local residents also came from the City of Medan and Padang Sidempuan. The production process is generally performed in order (made by order) due to limited manpower, facilities and infrastructure as well as the supply of raw materials, which until now is still obtained from nature. The composition of the raw materials referred to include plants such as Lemongrass (Cymbopogon citratus), Citronella (Cymbopogon nardus L), sembung Leafs (Blumea Balsamifera) Leaves scary place (Ageratum Conyzoides), Gotu kola Leaf (Centella Asiatica) and oldenlandia (Hedyotis Corymbosa). Then herbaceous-herbaceous is cleaned, chopped, cooked with Coconut Oil (Cocos Nucifera) as a carrier oil (a carrier oil) and pounded using stone mortar to produce an extract oil rub the herbaceous traditional (see figure 1). The process of extracting oil rub the traditional through the method of cooking is relatively lower nutrient content of the herbaceous-herbaceous there due to the high temperature of the oil.
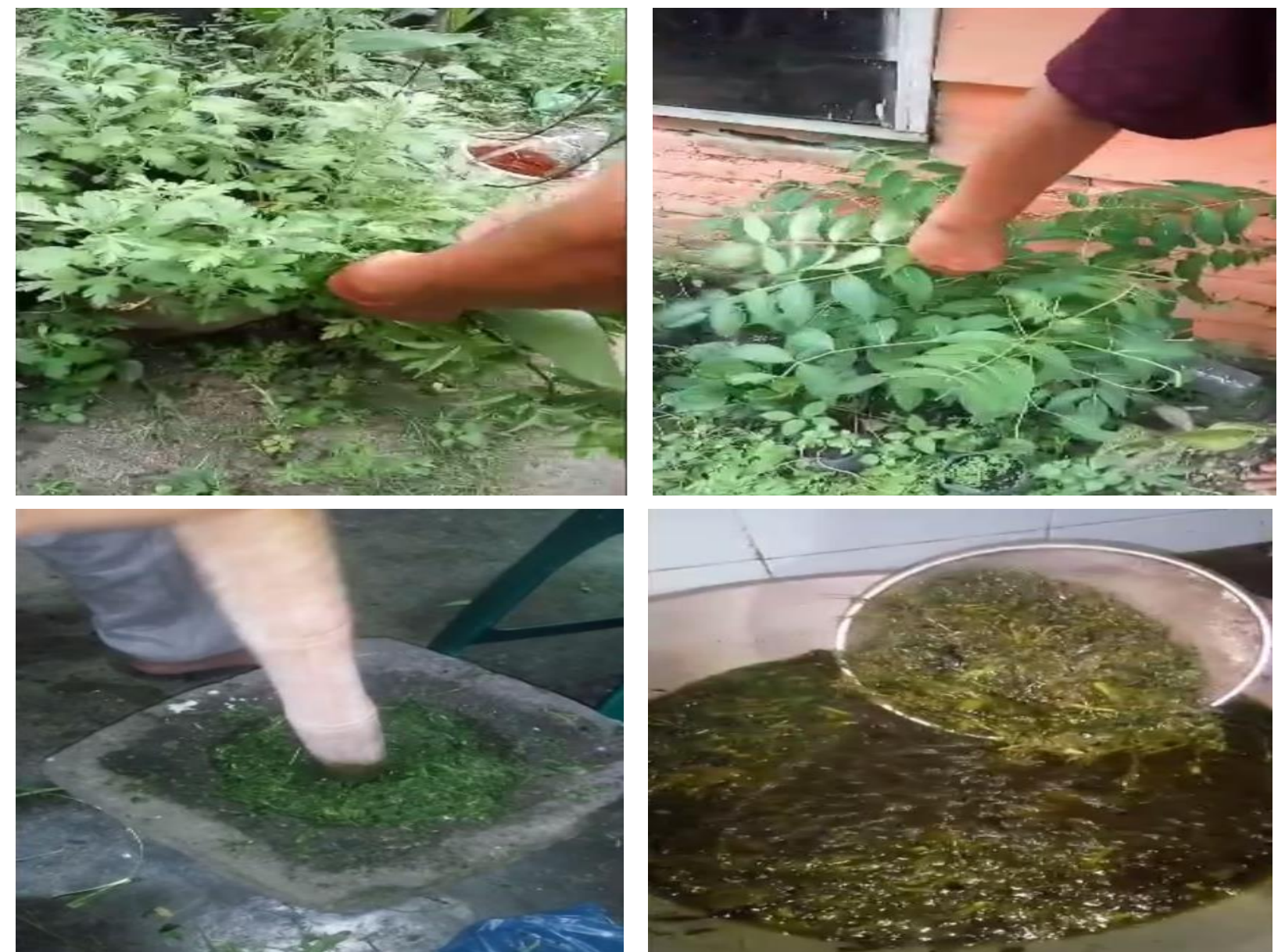

Figure 1. The Process of Plucking the Raw Material, Refining and Purification.

Although there has been no clinical study on the weight content of the oil rub that is produced as well; continuity of production and delivery of oil rub average per month as many as 100 bottles (size 140ml) shows the reputation of the product that is produced by Mr. Agus Hidayat through micro businesses with the name "Rambal Deli". Permission Micro and Small Enterprises (IUMK) "Rambal Deli" this has been registered in Department of Cooperatives and Small and Medium Enterprises in the District of Deli Serdang with the number 01.CM.T2016. 
In addition, herbal medicinal products produced by MSES Rambal Deli this has not got a certification-certification of another product to add to the competitiveness of the products produced by such certificate and permit release of product from the Food and Drug Supervisory Agency of the Republic of Indonesia (BPOM-RI) and the certificate of halal from the Indonesian Ulema council (MUI). In addition, according to the explanation of Mr. Agus Hidayat, in particular oil products rub this traditional herbal formulation is the development of oil rub Karo. However, as can be seen in figure 2, products-products produced by MSES Rambal Deli is not yet applying the technique of pe-brand (branding) and marketing mix, especially in the product packaging. So, the strengthening of marketing management through the certification of the relevant product can be a powerful platform for the protection of intellectual property as described in paragraph 3 of the previous.

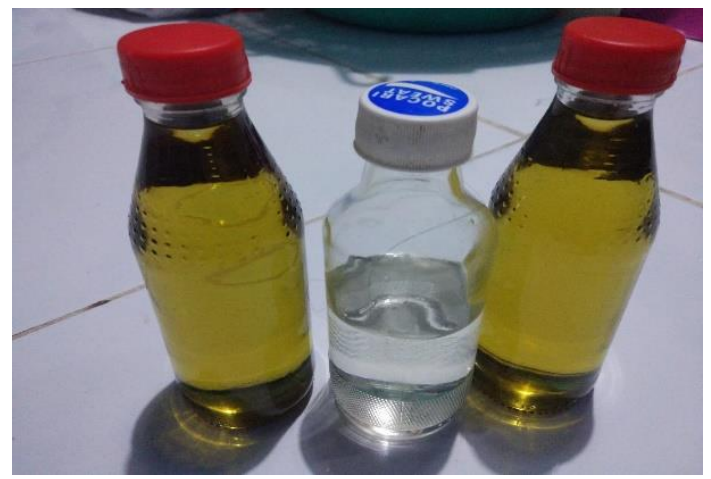

Figure 2. Samples of the Product Rub Oil without the Label.

PKM activity involves one (1) partners, namely the MSE Rambal Deli led by Mr. Agus Hidayat. UMK is located in the Street Sergeant M. Arifin gg. Muslim Lk. II village Galang Kota, Kecamatan Galang, Kabupaten Deli Serdang. In the activity of production and marketing of diary, Mr. Agus Hidayat assisted only by his wife and in some limited activity relevant. UMK Rambal Deli has been operating since the end of the 1990s however a new get a permit from the Department of Cooperatives and local SMES in the year 2016. Specific problems and Priority activities of the PKM with the title "the Actualization of the Increased Competitiveness of Oil Products Rub Herbaceous Traditionally Through Branding and Certification of Product Quality Assurance UMK Rambal Deli in Kecamatan Galang” is focused to the completion of 3 (three) specific problems that become priority issues. Table 1 lays out a matrix of specific problems and priority issues which meant.

Table 1. Matrix of Specific Problems and Priority Issues.

\begin{tabular}{|l|l|l|}
\hline No. & \multicolumn{1}{|c|}{ Specific Problems } & \multicolumn{1}{c|}{ Priority Issues } \\
\hline 1 & $\begin{array}{l}\text { The absence of the actualization of the explicit } \\
\text { knowledge (explicit knowledge) in the product } \\
\text { oil rub the herbs traditionally produced. }\end{array}$ & $\begin{array}{l}\text { There has been no effort to protect the } \\
\text { intellectual property rights of the products } \\
\text { produced. }\end{array}$ \\
\hline 2 & $\begin{array}{l}\text { Product competitiveness is relatively weak } \\
\text { with production management, marketing and } \\
\text { finance are still traditional. }\end{array}$ & $\begin{array}{l}\text { The marketing mix, especially on the product } \\
\text { packaging and marketing methods is still } \\
\text { relatively weak. }\end{array}$ \\
\hline 3 & $\begin{array}{l}\text { The products produced have received } \\
\text { certification of quality assurance are relevant. }\end{array}$ & $\begin{array}{l}\text { The acceleration of the fulfillment of the } \\
\text { aspects of production management relevant to } \\
\text { the certification of a quality assurance basis. }\end{array}$ \\
\hline
\end{tabular}

\section{SOLUTIONS AND TARGET OUTCOMES}

Alternative solutions to solve priority problems and output targets for this activity can be seen in the table below:

Table 2. Matrix of Priority Issues, Alternative Solutions and Target.

\begin{tabular}{|l|l|l|l|}
\hline No & \multicolumn{1}{|c|}{ Priority Issues } & \multicolumn{1}{|c|}{ Alternative Solutions } & \multicolumn{1}{c|}{ Final Target } \\
\hline 1 & $\begin{array}{l}\text { There has been no effort to protect } \\
\text { the intellectual property rights of } \\
\text { the products produced. }\end{array}$ & $\begin{array}{l}\text { Documentation profile and } \\
\text { product formulas for print and } \\
\text { electronic }\end{array}$ & $\begin{array}{l}\bullet \text { 1 (one) pocket books } \\
1 \text { (one) video }\end{array}$ \\
\hline 2 & $\begin{array}{l}\text { The marketing mix, especially on } \\
\text { the product packaging and } \\
\text { marketing methods is still } \\
\text { relatively weak. }\end{array}$ & $\begin{array}{l}\text { Modernization and strengthening } \\
\text { of the marketing mix: packaging } \\
\text { and marketing system }\end{array}$ & $\begin{array}{l}\text { Modern package with } \\
\text { (two) variants: } \\
\text { packaging bottle and } \\
\text { roll-on. } \\
\text { Modernization of } \\
\text { distribution channels }\end{array}$ \\
\hline
\end{tabular}




\begin{tabular}{|l|l|l|l|}
\hline 3 & $\begin{array}{l}\text { The acceleration of the fulfillment } \\
\text { of the aspects of production } \\
\text { management relevant to the } \\
\text { certification of a quality assurance } \\
\text { basis. }\end{array}$ & $\begin{array}{l}\text { Obtaining assistance certificate } \\
\text { of incorporation and business } \\
\text { license }\end{array}$ & $\begin{array}{l}\text { Submission } \\
\text { incorporation act } \\
\text { Submission business } \\
\text { license }\end{array}$ \\
\hline
\end{tabular}

\section{METHOD}

This activity includes 3 (three) stages of the actualization of the solutions to overcome the problems of partners where each stage consists of some specific steps as follows:

a. The Stage of Preimplementation Activities. In this stage, the proposer team to conduct the initial communication with partners to:

- Review the location.

- Identify the specific problems and issues of priority are used as the basis for the development of alternative solutions.

- Formulate and establish solutions which will be applied to the partners.

b. The Stage of Implementation Activities. This stage includes activities aimed at:

- In-depth discussion with the partners to visit the field related to the collection of information and documentation for the development of the profile and the formulation of the product as well as the manufacturing certificate and business license.

- Perform assistance related to the modernization of packaging and marketing systems.

c. The Stage of Post Implementation Activities. In this stage, the proposer team designing some of the key activities that are intended to:

- Ensure the realization of the achievement of activities in accordance with the budgeted targets.

- Compile the final report of the implementation of the activities.

The process of monev implemented through the mechanism of internal and external. Internally, $\mathrm{m} \& \mathrm{e}$ is done in a comprehensive manner by a team of proposer/implementer in all phases of the implementation of the activities. While the monev externally will be held by officers from the Community service Institute, State University of Medan (LPM UNIMED) as a process of quality assurance of the implementation of activities in accordance with the provisions of the policy institutional quality. Systematic activities carried out can be seen in the table below:

Table 3. The Implementation of Activities.

\begin{tabular}{|c|c|c|c|c|c|}
\hline No. & $\begin{array}{c}\text { Implementation } \\
\text { Activities }\end{array}$ & Method & Outcomes & Partners Participation & Date \\
\hline 1. & $\begin{array}{l}\text { Observation to } \\
\text { identify the initial } \\
\text { situation }\end{array}$ & $\begin{array}{lr}\begin{array}{l}\text { Conducted } \\
\text { observations }\end{array} & \begin{array}{r}\text { field } \\
\text { and }\end{array} \\
\text { interviews } & \text { with } \\
\text { partners } & \end{array}$ & $\begin{array}{l}\text { Partners profile, } \\
\text { problem } \\
\text { identification, } \\
\text { initial } \\
\text { documentation }\end{array}$ & $\begin{array}{l}\text { Preparing the data for the } \\
\text { in-depth interview and } \\
\text { meeting room }\end{array}$ & 22 May 2018 \\
\hline 2. & $\begin{array}{l}\text { The Formulation } \\
\text { Of The Solution }\end{array}$ & $\begin{array}{l}\text { FGD internal } \\
\text { among the team of } \\
\text { the proposer; and } \\
\text { further offered to } \\
\text { partners. }\end{array}$ & An agreed solution & $\begin{array}{l}\text { Partners provide } \\
\text { feedback related to the } \\
\text { solution offered, be } \\
\text { cooperative, and to reach } \\
\text { agreement of the solution } \\
\text { with the proposer team. }\end{array}$ & 19 June 2018 \\
\hline 2. & $\begin{array}{l}\text { The provision of } \\
\text { training } \\
\text { theoretical and } \\
\text { simulation } \\
\text { technical about } \\
\text { the business } \\
\text { strategies and } \\
\text { product } \\
\text { packaging }\end{array}$ & $\begin{array}{l}\text { Participatory, } \\
\text { group discussion } \\
\text { and Consultation }\end{array}$ & $\begin{array}{l}\text { The efficiency and } \\
\text { productivity of the } \\
\text { business. Judging } \\
\text { from the reduction } \\
\text { of working time and } \\
\text { increased income }\end{array}$ & $\begin{array}{l}\text { Provide training, } \\
\text { Participate and play an } \\
\text { active role during the } \\
\text { event }\end{array}$ & $\begin{array}{c}4 \\
\text { November } \\
2018\end{array}$ \\
\hline 4. & $\begin{array}{l}\text { Provision of } \\
\text { company } \\
\text { establishment } \\
\text { certificate and } \\
\text { business license }\end{array}$ & $\begin{array}{l}\text { Handover, } \\
\text { certificate and } \\
\text { business license }\end{array}$ & $\begin{array}{l}\text { The articles of } \\
\text { incorporation, } \\
\text { SIUP, TDP }\end{array}$ & $\begin{array}{l}\text { Sign the news event of } \\
\text { the surrender of the } \\
\text { certificate }\end{array}$ & $\begin{array}{l}4 \\
\text { November } \\
2018\end{array}$ \\
\hline
\end{tabular}




\section{IMPACT OF ACTIVITIES}

The activities of The Community as a whole implemented since May 22, 2018 to 10 October 2018. Most of the activities carried out by correspondence and consultation with the communication media. While it is a formal activity and direct interaction remains to be the main agenda in this service activity. Various face to face activities and the implementation of the training held in November. This activity has resulted in several outcomes. The description of the outcomes-outcomes that can be reviewed as follows:

1) Management of the certificate of incorporation of UD.Rambal Deli.

2) Obtaining a business license SIUP and TDP UD.Rambal Deli.

3) Productivity: the Submission of the bottle impermeable to the rays of the sun and the bottles roll on the mini so more varied product packaging that is produced and keep the product more durable. From the results of this can be seen increased productivity with produces more oil rub and packed inside the bottle are more varied, so increased sales.

4) Marketing: Submission of the design of the packaging in the form of a sticker that has already been printed, so that the resulting product has packaging and brands that are interesting, and can increase confidence of the buyer so that the sales also increase.

5) Publication in the mass Media: a variety of activities that have been done by the Executive Team in the village of Galang has been published in the Daily Terrain of Business on Saturday 17 March 2018, and can be accessed online on the site medanbisnisdaily.com with the title "LPM Unimed Do Mentoring Certification of Products Based on Local Wisdom".

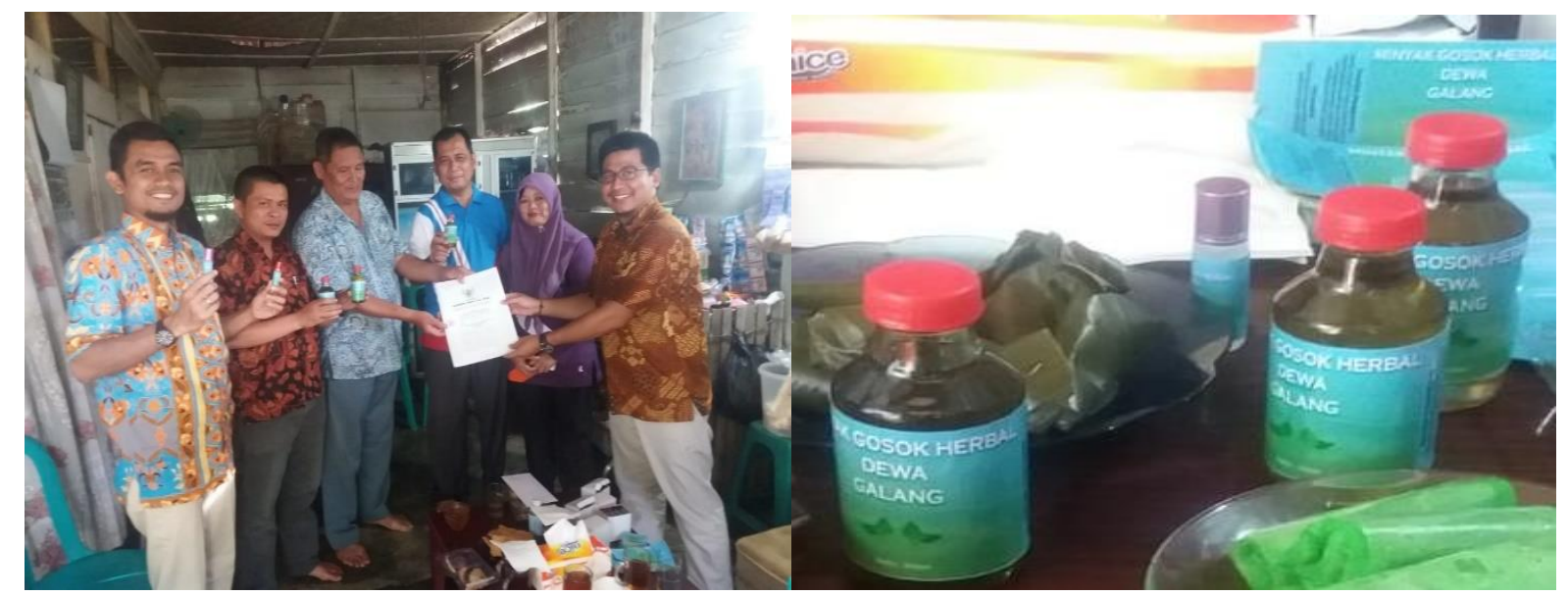

Figure 3. Community Service Activity Delivery of Certificate and Sticker Packaging.

\section{CONCLUSION AND SUGGESTIONS}

Based on the results of the activities of the community in the village of galang and of the concepts and results of the mentoring that has been done then the conclusion and the advice given is as follows:

1) UD. Rambal Deli has had a certificate of incorporation and a letter of permission of business, i.e. SIUP and TDP.

2) UD. Rambal Deli has diversified packaging with a bottle that is impermeable to sunlight and the bottles roll on the mini and has done branding or brand by attaching the sticker print dibotol oil rub.

3) UD. Rambal Deli requires clinical trials of the product oil gosoknya in order to be certified BPOM and Halal to be performed on the service activities of the next.

4) Online marketing is also needed by the UD. Rambal Deli to increase sales and on the next, service we will be assisting to create a media marketing and online store.

5) Stakeholders (Scientists, Academics, Practitioners, Government) should be able to appreciate the initiative of the MSE. Furthermore, the appreciation should be transformed into the giving of attention and the role of both direct and indirect that can support the performance of financial and non-financial SME so that it can achieve its main goal, namely the improvement of the economy of the community. 